\title{
Herpes simplex keratitis
}

Human herpesvirus type 1 or herpes simplex virus type 1 (HSV-1) belongs to the herpetoviridae family, six members of which (human herpesviruses 1-6) have been linked to human ocular disease. HSV-1 is a large DNA enveloped virus, with a diameter 150-200 nm, comprising an internal core (containing a genome with $c$. 70 open reading frames), a surrounding icosahedral protein capsid, a tegument and an outer envelope.

\section{Epidemiology and transmission}

HSV-1 is the most common infective cause of blindness in many developed countries, with an incidence of keratitis between 5.9 and 20.7 episodes $/ 100000$ person years $[1,2]$. Ocular infections occurring for the first time in an individual may represent a primary infection, or a new anatomic site within a previously infected host. Involvement of the lids, conjunctiva and superficial cornea are the most common manifestations of primary ocular herpes.

It is difficult to assess the incidence of primary ocular herpes as it is not known what percentage are asymptomatic and because the diagnosis requires evidence of seroconversion. Even this latter point may be debatable as HSV-1 antibody may be found in the tear film of seronegative individuals [3]. Among children, the incidence of primary ocular herpes ranges between 1 in $8000-1$ in 24000 and 1 in $3500-1$ in 30000 based on the assumption that this is likely to represent the child's first encounter with the virus $[1,4]$. In general, primary ocular herpes parallels the incidence of oral herpes, where the peak age of acquisition is before the age of 3 years among the lower socio-economic groups.

Most of the morbidity associated with ocular herpes lies in its ability to recur. This usually manifests clinically as corneal ulceration or a stromal keratitis herpes simplex keratitis (HSK) - or both. Recurrence rates vary from $9.6 \%$ at 1 year, $22.9-33 \%$ at 2 years after two episodes, $40 \%$ at 5 years, to $67 \%$ at 7 years $[1,2,4,5]$. The rate of recurrence increases in direct proportion to the number of episodes. Each recurrence leads to further corneal scarring and vascularisation, which increases the risk of corneal graft rejection. Furthermore, patients who have had corneal transplantation, are still at risk of further recurrences.

\section{Entry of HSV into the host}

Virus replication probably occurs at the site of inoculation, which ensures contact with and entry into the sensory nerve endings. This also results in the production of neutralising antibodies. It may be equally important for HSV-1 to multiply in the ganglion before the immune system has responded, although evidence suggests that control of multiplication by class 1 restricted $\mathrm{CD}^{+}$cytotoxic $\mathrm{T}$ lymphocytes decreases spread into the brain stem [6]. In mice, $T$ cells tend to persist and $\gamma$-interferon appears to be expressed after the establishment of latency [7], possibly in response to low level expression of 'immediate-early' HSV proteins during latency [7-9].

\section{Neuronal spread of HSV}

HSV is transported within the axon by axoplasmic flow, at a rate of $2-20 \mathrm{~mm} / \mathrm{h}$ [10] towards the CNS [11], where the virus may interact with the cell nucleus [12] to establish latent or productive infection. Within the trigeminal ganglion, infection is largely restricted to neurones, with little intraganglionic spread to other neurones [10], although this may be possible [13]. Virus transported centrally reaches the nerve root where it may leave the axon to infect astrocytes and oligodendroglial cells [11]. Infection of such cells may then allow virus to enter contiguous axons leading to 'zosteriform' spread [11]. This may explain why the exact site of primary and recurrent disease can differ. It is probable that virus is transported as a non-infectious nucleocapsid and is enveloped in the distal axon [14].

\section{Latency}

The determination of which tissues harbour latent virus is important for understanding the pathogenesis of recurrent disease. The trigeminal ganglion is known to contain latent virus. During latency, the latencyassociated transcripts (LATs) appear to be the only transcripts expressed, although there are very low levels of 'immediate-early' gene expression [8,9]. Marker studies [15] indicate that defective viral genomes may also reside in human ganglion cells. LATs are abundant in latently infected human, rabbit and murine trigeminal ganglia and the number of neurones expressing LAT per genome is far higher in 
the trigeminal ganglion than in the brain stem $[16,17]$. LATs do not appear to be necessary for the establishment or maintenance of latency, but are necessary for efficient viral reactivation [18]. LAT transcription is enhanced in both neuronal and non-neuronal cells by the LAT promoter binding factor [19]. Possibly suboptimal 'immediate-early' expression $[8,9]$ due to inefficient promoter function results in latency and LAT expression [7-9].

\section{Corneal latency}

The cornea is a possible site for harbouring latent virus [20]. Viral antigens have been demonstrated in corneal discs taken from patients with previous HSK and HSV-1 has been isolated from the cornea of $12-$ $29.4 \%$ of patients with previous HSK at transplantation [20].

HSV DNA has also been found in the corneas of patients with previous herpetic keratitis [21,22], apparently non-herpetic corneal disease [21-23] and in eye bank corneas unsuitable or not used for transplantation $[23,24]$. The significance of persistent HSV DNA in the cornea is unclear although it suggests that asymptomatic and unrecognised herpetic infections of the cornea are more common than realised. Corneal and neuronal cells regulate the LAT promoter in a similar manner [25] and the finding of LAT transcripts in the absence of glycoprotein $\mathrm{gC}$ transcription [22] provides further evidence for the possibility of corneal latency. The limited transcription observed may represent defective genomes $[12,15]$. Attempts to detect HSV-1 LATs by in-situ hybridisation in the human cornea have so far failed. Whether this represents a difference in sensitivity between in-situ hybridisation and PCR is not known.

\section{How virus reaches the eye: back or front door?}

The frequent occurrence of asymptomatic salivary shedding of HSV-1 [26] implicates the mouth as the main site for the acquisition and spread of HSV-1 within the community. Asymptomatic shedding of HSV in the tear film appears to be much less common [26]. Tullo et al. [27] suggested the idea of a 'backdoor' route to ocular disease. Following lower lip inoculation of the mouse, HSV has been recovered from all three divisions of the trigeminal ganglion [27], which suggests that after an oral infection, HSV can establish a latent infection in ophthalmic neurones via the CNS. However, Baringer and Griffith [28] found that lesions are restricted to the ophthalmic division of the trigeminal nerve, following inoculation of the rabbit cornea. Furthermore, HSV has not been recovered from the cornea or tear film after lower lip inoculation of the mouse.
Asymptomatic primary herpetic eye disease may be important in the development of recurrent corneal disease. The frequent detection of HSV DNA in diseased and some non-diseased (eye bank) corneas [20-24] is consistent with the occurrence of asymptomatic or unrecognised HSV-1 ocular infection. Furthermore, the finding of secretory anti-HSV-1 antibody in the tear film of individuals who do not have serum anti-HSV antibody [3], also suggests that the eye may be a primary portal of entry for HSV and that spread beyond the eye need not necessarily occur.

In mice, droplet spread of HSV to the eye in titres similar to those found in saliva results in disease similar to that of primary ocular herpes [29]. In addition, HSV can be isolated from the trigeminal ganglion and iris, and HSV DNA can be found in these tissues as well as the cornea [29]. This supports the idea that HSV-1 can spread into the cornea, iris and trigeminal ganglion, after topical application of virus to the eye. This non-traumatic acquisition of virus by the mouse eye suggests that asymptomatic primary infection in man may lead to a latent infection of the trigeminal ganglion and possibly of the iris and cornea.

As with lower lip inoculation, it has yet to be established whether virus presented by this route can be reactivated in the trigeminal ganglion, iris and cornea to produce recurrent disease.

As HSV cannot be eradicated from the latent state and ocular recurrences cannot be presented, primary prevention is the main approach to herpetic disease of the eye. The question of whether virus introduced directly into the eye by droplet spread is more or less able to produce recurrent eye disease than virus acquired through the mouth is crucial to this strategy.

S. B. KAYE Department of Medical Microbiology and Genito-urinary Medicine, University of Liverpool.

K. BAKER The Department of Ophthalmology, Royal Liverpool Children's NHS Trust.

\section{References}

1. Liesegang TJ, Melton LJ, Daly PJ, Ilstrup DM. Epidemiology of ocular herpes simplex. Incidence in Rochester, Minn, 1950 through 1982. Arch Ophthalmol 1989; 107: 1155-1159.

2. Norn MS. Dendritic (herpetic) keratitis, I: incidence - seasonal variations - recurrence rate - visual impairment - therapy. Acta Ophthalmol 1970; 48: 91-107.

3. Coyle PK, Sibony PA. Viral antibodies in normal tears. Invest Ophthalmol Vis Sci 1988; 29: 1552-1558.

4. Ribaric V. The incidence of herpetic keratitis among population. Ophthalmologica 1976; 173: 19-22.

5. Shuster JJ, Kaufman HE, Nesburn AB. Statistical analysis of the rate of recurrence of herpesvirus ocular epithelial disease. $A m J$ Ophthalmol 1981; 91: 328-331.

6. Nash AA, Cambouropoulos P. The immune response to herpes simplex virus. Semin Virol 1993; 4: 181-186. 
7. Cantin EM, Hinton DR, Chen J, Openshaw H. Gamma interferon expression during acute and latent nervous system infection by Herpes Simplex Virus type 1. J Virol 1995; 69: $4898-4905$.

8. Kosz-Vnenchak M, Jacobson J, Coen DM, Knipe DM. Evidence for a novel regulatory pathway for herpes simplex virus gene expression in trigeminal ganglion neurons. $J$ Virol 1993; 67: 5383-5393.

9. Kramer MF, Coen DM. Quantification of transcripts from the ICP4 and thymidine kinase genes in mouse ganglia latently infected with herpes simplex virus. J Virol 1995; 69: 13891399.

10. Cook ML, Stevens JG. Pathogenesis of herpetic neuritis and ganglionitis in mice: evidence for intra-axonal transport of infection. Infect Immunity 1973; 7: 272-288.

11. Hill TJ. Ocular pathogenicity of herpes simplex virus. Curr Eye Res 1987; 6: 1-7.

12. Roizman B, Sears AE. The herpes simplex viruses and their replication. In: Fields BN, Knipe DM (eds) Fields Virology, 2nd edn. New York, Raven Press Ltd. 1990: 1795-1841.

13. Martin JR, Jenkins FJ, Henken DB. Targets of herpes simplex virus type 1 infection in a mouse corneal model. Acta Neuropathol 1991; 82: 353-363.

14. Penfold ME, Armati P, Cunningham AL. Axonal transport of herpes simplex virions to epidermal cells: evidence for a specialized mode of virus transport and assembly. Proc Natl Acad Sci USA 1994; 91: 6529-6533.

15. Brown SM, Subak-Sharpe JH, Warren KG, Wroblewska Z, Koprowski $H$. Detection by complementation of defective or uninducible (herpes simplex type 1) virus genomes latent in human ganglia. Proc Natl Acad Sci USA 1979; 76: 2364 2368.

16. Ramakrishnan R, Fink DJ, Jiang G, Desai P, Glorioso JC, Levine $M$. Competitive quantitative PCR analysis of herpes simplex virus type $1 \mathrm{DNA}$ and latency-associated transcript RNA in latently infected cells of the rat brain. $J$ Virol $1994 ; \mathbf{6 8}$ : 1864-1873.

17. Ramakrishnan R, Levine M, Fink DJ. PCR-based analysis of herpes simplex virus type 1 latency in the rat trigeminal ganglion established with a ribonucleotide reductase-deficient mutant. J Virol 1994; 68: 7083-7091.
18. Leib DA, Nadeau KC, Rundle SA, Schaffer PA. The promoter of the latency-associated transcripts of herpes simplex virus type I contains a functional cAMP-response element: role of the latency-associated transcripts and cAMP in reactivation of viral latency. Proc Natl Acad Sci USA 1991; 88: 48-52.

19. Zwaagstra JC, Ghiasi H, Slanina SM et al. Activity of herpes simplex virus type 1 latency-associated transcript (LAT) promoter in neuron-derived cells: evidence for neuron specificity and for a large LAT transcript. $J$ Virol 1990; 64: 50195028 .

20. Easty DL, Shimeld C, Claoue CMP, Menage M. Herpes simplex virus isolation in chronic stromal keratitis: human and laboratory studies. Curr Eye Res 1987; 6: 69-74.

21. Cantin EM, Chen J, McNeill J, Willey DE, Openshaw $\mathrm{H}$ Detection of herpes simplex virus DNA sequences in corneal transplant recipients by polymerase chain reaction assays. Curr Eye Res 1991; 10 Suppl: 15-21.

22. Kaye SB, Lynas C, Patterson A, Risk JM, McCarthy K, Hart $\mathrm{CA}$. Evidence for herpes simplex viral latency in the human cornea. Br J Ophthalmol 1991; 75: 195-200.

23. Openshaw H, McNeill JI, Lin XH, Niland J, Cantin EM. Herpes simplex virus DNA in normal corneas: persistence without viral shedding from ganglion. $J$ Med Virol 1995; 46: 75-80.

24. Cleator GM, Klapper PE, Dennett C et al. Corneal donor infection by herpes simplex virus: herpes simplex virus DNA in donor corneas. Cornea 1994; 13: 294-304.

25. Perng GC, Zwaagstra JC, Ghiasi $\mathrm{H}$ et al. Similarities in regulation of the HSV-1 LAT promoter in corneal and neuronal cells. Invest Opthalmol Vis Sci 1994; 35: 2981-2989.

26. Kaye SB, Madan N, Dowd TC, Hart CA, McCarthy K, Patterson A. Ocular shedding of herpes simplex virus. $\mathrm{Br} J$ Ophthalmol 1990; 74: 114-116.

27. Tullo AB, Easty DL, Hill TJ, Blyth WA. Ocular herpes simplex and the establishment of latent infection. Trans Ophthalmol Soc $U K$ 1982; 102: 15-18.

28. Baringer JR, Griffith JF. Experimental herpes simplex encephalitis: early neuropathologic changes. $J$ Neuropathol Exp Neurol 1978; 29: 89-104.

29. Kaye SB, Shimeld C, Grinfeld E, Maitland NJ, Hill TJ, Easty DL. Non-traumatic acquisition of herpes simplex virus infection through the eye. Br $J$ Ophthalmol 1992; 76: 412-418. 